\title{
Empoasca papayae Oman, 1937 (Hemiptera: Cicadellidae) the simultaneous vector of phytoplasmas and rickettsia associated with "Bunchy Top Symptom" in Cuba
}

Karel Ismar Acosta ${ }^{1}$, Loidy Zamora², Berta Piñol ${ }^{2}$, Madelaine Luisa Quiñones ${ }^{2}$, Pedro Luis Ramos ${ }^{3}$, Maritza Luis ${ }^{3}$, Norma Elena Leyva-López ${ }^{4}$ \& Yaima Arocha ${ }^{5}$

1 Universidad de Las Tunas (ULT), Las Tunas, 75200, Cuba.

2 Centro Nacional de Sanidad Agropecuaria (CENSA), San José de Las Lajas, Mayabeque, 32700, Cuba.

3 Instituto de Investigaciones en Fruticultura Tropical (IIFT), Miramar, Ciudad de La Habana, 11300, Cuba.

4 Instituto Politécnico Nacional, CIIDIR, Unidad Sinaloa, Departamento de Biotecnología Agrícola, Blvd. Juan de Dios Batiz Paredes No. 250, San Joachin, C.P. 81101, Guasave, Sinaloa, México.

5 Sporometrics, Toronto, Ontario, Canada, M6K 3J1.

Correspondence

K.I. Acosta

E-mail: karel0978@gmail.com

Received: 6 October 2016

Accepted: 16 January 2017

Published on-line: 8 February 2017

\section{Resumen}

Ensayos de transmisión mostraron desarrollo de síntomas típicos de BTS en todas las plantas de papaya después de tres meses de post-inoculadas con Empoasca papayae. El fitoplasma identificado en 28 de 45 las plantas inoculadas, presentó, en secuencia de ADN ribosomal $16 \mathrm{~S}$, un $99,9 \%$ igual al identificado en plantas de campo y con las detectadas previamente en E. papayae en Cuba. Todos son miembros del subgrupo de fitoplasma $16 \mathrm{Srl}-\mathrm{B}$. Una rickettsia se identificó en 41 de las 45 plantas inoculadas. Su secuencia parcial del gen sdhA mostró un $100 \%$ de identidad con la rickettsia identificada en plantas de campo, E. papayae y las previamente publicadas. Los resultados confirmaron la habilidad de $E$. papayae para transmitir simultáneamente el fitoplasma y la rickettsia.

Palabras clave: Saltahojas, Transmisión, Fitoplasma, Rickettsia.

\begin{abstract}
Empoasca papayae Oman, 1937 (Hemiptera: Cicadellidae) vector simultáneo de phytoplasmas y rickettsia asociadas a "Bunchy Top Symptom" en Cuba
\end{abstract}

Transmission trials showed typical BTS symptoms developed in all papaya plants after three months post-inoculated with Empoasca papayae. The BTS phytoplasma was identified in 28 out of 45 inoculated papayas, whose partial $16 \mathrm{~S}$ rDNA sequence was $99.9 \%$ identical to those of the phytoplasma identified in the field-collected papayas, and that previously detected in E. papayae in Cuba. These are all members of the phytoplasma subgroup 16Srl-B. A rickettsia was identified in 41 out of 45 inoculated papayas. It showed a $100 \%$ of identity of its partial sdhA sequence to those from the field-collected papayas, E. papayae and the rickettsia previously identified. Results confirmed the ability of $E$. papayae to simultaneously transmit the BTS phytoplasma and the rickettsia pathogen.

Key words: Leafhopper, Transmission, Phytoplasma, Rickettsia. 


\section{Introduction}

Papaya Bunchy Top (PBT) is a major limiting factor in papaya production in some areas of the Caribbean region. PBT is widely distributed in Central American and Caribbean countries, and was associated with a rickettsia transmitted by Empoasca papayae Oman, 1937 (Hemiptera: Cicadellidae) in Puerto Rico (Davis et al. 1998).

Bunchy Top Symptom (BTS) included stunting and shortening of internodes of the inner crown leaves, which show deformation, crinkling, and yellowing symptoms. In some cases, petioles are rigid, extending more horizontally than normal from the main stem. In general, the affected plants develop chlorosis, stunting, abscission of the fruit, and a marked reduction in latex flow. In advanced stages, stunting and yellowing are seen in BTS affected plants showing leaf necrosis and no flowering or fruit-set occurs. The diseases producing high loss in papaya crop in Cuba (Arocha et al. 2003).

A mixed infection of two phytoplasma groups (16SrI-X and 16SrII-N subgroups) identified from BTS-affected papaya plants and a rickettsia was informed in Havana and Las Tunas provinces of Cuba. The phytoplasmas are consistently associated with both BTS and PBT symptoms, and the mixed infections of phytoplasma and rickettsia pathogens can occur in either BTS or PBTaffected papaya fields, which implies new epidemiological constraints for the disease control (Acosta et al. 2013).

These two phytoplasma groups have been identified from BTS-affected papaya plants in Cuba. The group 16SrII ("Candidatus Phytoplasma aurantifolia") was associated with BTS in the eastern region of the country (Arocha et al. 2006, 2007), whereas a phytoplasma of the group 16SrI ("Candidatus Phytoplasma asteris", 16SrI-B subgroup) was associated with papaya exhibiting BTS-like symptoms in eastern Cuba (Acosta et al. 2011) and BTS symptom in western (Havana province) (Acosta et al. 2013).

E. papayae was identified as the vector of the 16SrII phytoplasma that causes BTS in Cuba (Acosta et al. 2010). However, evidences of its capacity to transmit the $16 \mathrm{SrI}$ phytoplasma and/or the rickettsia pathogens are required to provide plant health authorities with confirmed information to develop more effective control strategies.
The present study reports the experimental transmission of the rickettsia and the 16SrI phytoplasma associated with BTS by E. papayae, which confirms the simultaneous vector capacity of this Cicadellidae leafhopper for both plant pathogens to the papaya.

\section{Materials and methods}

\section{Sample collection and reference controls}

Surveys were conducted in papaya fields (cv. Maradol Roja) in the Mayabeque province. Leaf samples were randomly collected from 45 papaya plants displaying typical BTS symptoms. Leaf samples were also collected from 10 symptomless papaya plants. DNA was extracted according to Davis et al. (1998) with some modifications (Acosta et al. 2013). Total DNA of leaf samples from symptomatic and symptomless papayas were used for PCR-based analysis.

During the same survey of BTS-affected papaya plantations, 120 "five instar" nymphs and 40 adults of $E$. papayae were collected by vacuum sampling (Moir et al. 2005). Sixteen male adults of $E$. papayae were selected for taxonomical identification. Specimen adults and nymphs were randomly sorted in batches of three. Forty-five $E$. papayae nymphs (15 batches) and 24 adults (8 batches) were indexed by PCR for phytoplasma and rickettsia. The remaining E. papayae nymphs (75) were immediately used for transmission trials.

Reference controls for phytoplasmas included total DNA from phytoplasma strains representatives of group 16SrI: aster yellows, AY; and group 16SrII: crotalaria witches" broom, subgroup 16SrII-A (CroWB); faba bean phyllody, subgroup 16SrII-C (FBP); and tomato big bud, subgroup 16SrII-D (TBB) from the Rothamsted Research collection (UK), and DNA of papaya plants infected with uncultured rickettsia strain PBTr-ULT01 from Las Tunas province.

\section{Transmission trials}

Forty-five healthy certified seeds (15/cultivar/cage) of papaya cultivars (Maradol Roja, Tainung- 1 and Scarlet Princess) were germinated in mesh cages in an insect proof greenhouse and used for the transmission trials 45 days after germination. Five seedlings of each papaya 
cultivar were used as non-inoculated controls in a separate mesh cage. Twenty "five instar" $E$. papayae nymphs, collected from the BTS-affected field, were allowed an inoculation access period of 30 days on each cage with healthy papaya. Following the inoculation period, insects were sprayed with insecticide and a group of forty-five (15 batches, five each cultivar) was indexed by PCR and the other group of 15 insects was preserved for further taxonomical identification. Post-inoculated plants were monitored for symptom development for six months, and tested monthly by PCR and sequencing to confirm the phytoplasma and/or rickettsia infection.

\section{Phytoplasma and rickettsia detection by PCR}

A nested PCR assay with universal primers that target the phytoplasma 16S rRNA gene was used to amplify a $1.45 \mathrm{~kb}$ fragment from the first round PCR (R16mF2/R1), and a $1.25 \mathrm{~kb}$ amplicon from the nested reaction (R16F2n/R16R2) (Gundersen and Lee 1996). For both primer pairs, PCR was performed in 35 cycles of $1 \mathrm{~min}$ at $95{ }^{\circ} \mathrm{C}(4$ minutes at $95{ }^{\circ} \mathrm{C}$ for the initial denaturation), 1 min at $60{ }^{\circ} \mathrm{C}\left(55{ }^{\circ} \mathrm{C}\right.$ for $\mathrm{R} 16 \mathrm{~F} 2 \mathrm{n} / \mathrm{R} 16 \mathrm{R} 2$ primer pair), and 2 min at $72{ }^{\circ} \mathrm{C}$, and a final extension cycle of $5 \mathrm{~min}$ at $72{ }^{\circ} \mathrm{C}$. The PCR amplification for rickettsia was performed with primers that specifically amplify a $705 \mathrm{bp}$ fragment of the rickettsial succinate deshydrogenase $(s d h \mathrm{~A})$ gene (Davis et al. 1998).

PCR amplifications for both pathogens were conducted in an automated thermocycler (model iCycler, Bio-Rad, USA) in a final volume of 25 $\mu \mathrm{L}$ containing $1 \mathrm{U}$ of Taq DNA polymerase (Invitrogen Life Technologies, Brazil); $200 \mathrm{mM}$ of each $\mathrm{dNTP}$, and 0.4 pmoles of each primer. PCR reactions using deionized sterile water were used as PCR negative controls. PCR products were analysed by electrophoresis in a $1 \%$ agarose gel and visualized by staining with ethidium bromide $(2 \mathrm{mg} / \mu \mathrm{L})$ under a UV transilluminator.

\section{RFLP analysis of phytoplasma amplicon}

R16F2n/R16R2 PCR fragments of 12 representative samples, two for each phase transmission trials (BTS affected papaya plants and E. papayae nymphs collected on field, E. papayae adults and BTS affected papaya plants of the three cultivars post-inoculated) were digested with $A l u \mathrm{I}$ and $M s e \mathrm{I}$ restrictions endonuclease according to the manufacturer"s instructions (Invitrogen Life Technology, USA) for group differentiation. Random fragment length polymorphism (RFLP) products were visualized in a 3\% agarose gel stain with ethidium bromide under UV transilluminator. RFLP patterns of phytoplasma and rickettsia were compared with those phytoplasma controls previously reported (Lee et al. 1998) and with those rickettsia controls (Acosta et al. 2013), respectively.

\section{Cloning of PCR products, sequencing of DNA and phylogenetic analysis}

Both R16F2n/R16R2 and rickettsial sdhA PCR products were purified using a Genclean III Kit (Gibco-BRL) and ligated onto a pGEM-T Easy vector (Promega, USA). Plasmid DNA was purified using QIAprep Spin Miniprep Kit (QIAGEN $\mathrm{GmbH}$, USA) and each plasmid DNA was sequenced bidirectionally in an ABI PRISM 377 sequencer using the Dye cycle sequencing kit (Applied Biosystems, Foster City, CA) three times. The partial $16 \mathrm{~S}$ rDNA and rickettsia $s d h \mathrm{~A}$ sequences were compared with those of the references in GenBank by BLAST (Altschul et al. 1990).

The R16F2n/R2 16S rDNA sequences from the phytoplasmas were aligned with those of other phytoplasma groups and Acholeplasma laidlawii by the MUSCLE algorithm (Edgar 2004). The rickettsial $s d h \mathrm{~A}$ sequences were aligned with other rickettsia strains from GenBank. Phylogenetic trees were constructed using the neighbourjoining method with the program MEGA version 6.06 (Tamura et al. 2013). Bootstrapping with 3000 replicates was performed to estimate the stability and support the branches.

\section{Results}

\section{Symptom development}

All post-inoculated papayas, except the controls, developed BTS symptoms within the first three months after insect-inoculation (Fig. 1). Symptoms started as a light leaf chlorosis and mosaic, followed by interveinal yellowing. Four to five months after infection symptoms of stunting, lower latex flow and bunchy appearance of the crown younger leaves were evident (Fig. 1). 


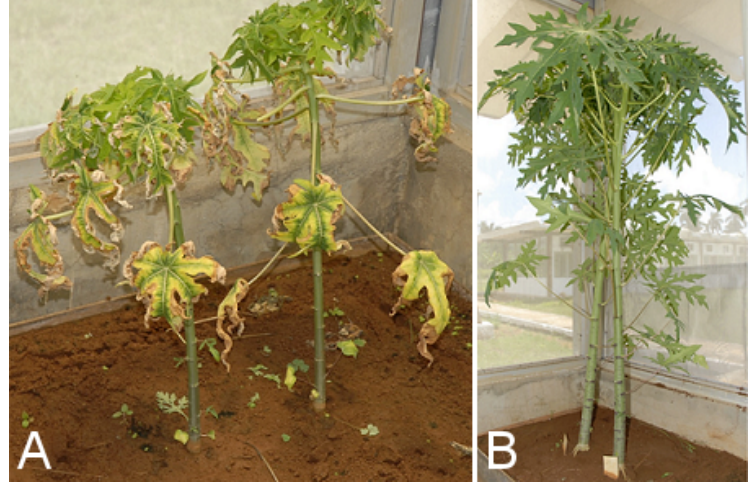

Figura 1. Síntomas de BTS desarrollados dentro de tres primeros meses después de inoculación con E. papayae (A) y plantas controles (B).

Figure 1. Developed BTS symptoms within the first three months after E. papayae inoculation (A) and control plants (B).

\section{Phytoplasma and rickettsia detection by PCR}

Phytoplasmas were detected by nested PCR in 36/45 BTS-affected papaya plants, $9 / 15$ batches of E. papayae nymphs and $6 / 8$ batches of $E$. papayae adults collected in the field, $8 / 15$ batches of $E$. papayae and 27/45 BTS-affected papaya plants post-inoculated (Table 1).

Rickettsia were detected by PCR in $42 / 45$ BTS-affected papaya plants and 12/15 batches of $E$. papayae nymphs and $5 / 8$ batches of $E$. papayae adults collected in the field, 10/15 batches of E. papayae and 22/45 BTS-affected papaya plants post-inoculated (Table 1).

Phytoplasma and rickettsia pathogens were simultaneously detected in: 36 samples of BTSaffected papaya plants and eight batches of $E$. papayae nymphs and four batches of $E$. papayae adults collected in the field, in seven batches of $E$. papayae and $20 \mathrm{BTS}$-affected papaya plants postinoculated (Table 1). No amplification was observed from total DNA extracted from healthy plants collected in the field and used as noninoculated controls in the transmission trials.

\section{RFLP analysis of detected phytoplasmas}

RFLP analysis with $A l u$ I (Fig. 2A) and MseI (Fig. 2B) endonuclease restriction enzymes of representative R16F2n/R16R2 amplicon of the BTS phytoplasma (BTSp) amplified from E. papayae and papaya plants from the field and the transmission trials were identical to each other.

BTSp strains of papaya plants surveyed in the field (BTSp-IB-Field), E. papayae collected in the field and used in the transmission trial (BTSp-IB-

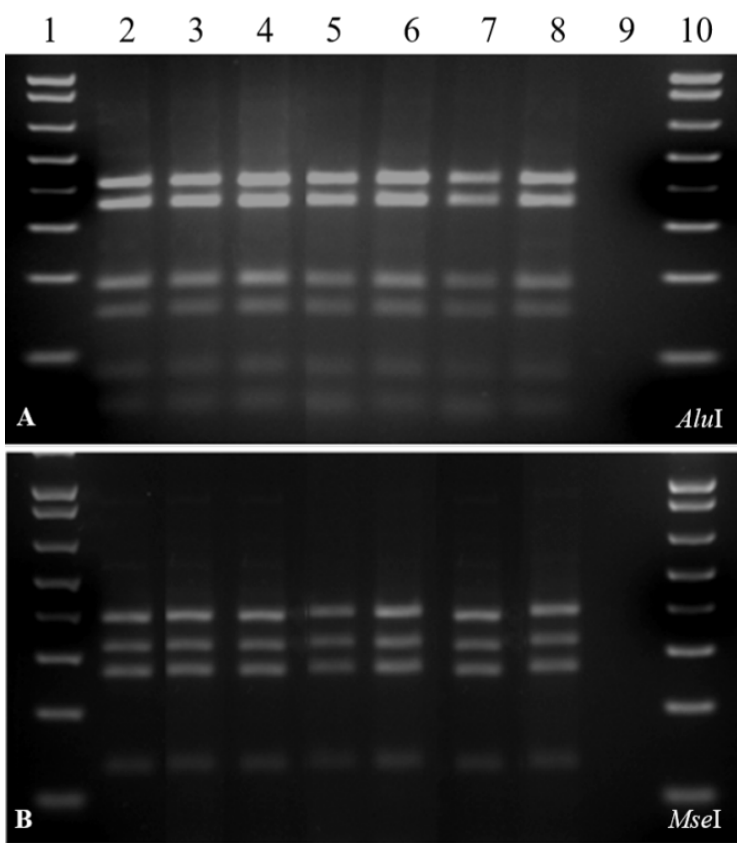

Figura 2. Patrones de RFLP de $A l u \mathrm{I}$ (A) y MseI (B) basados en las secuencias de ADNr 16S de BTSp. Carriles 2, 3: plantas de papaya y $E$. papayae colectados en campo. Carriles 4, 5: $E$. papayae empleado en el ensayo de transmisión. Carriles 6, 7: Plantas de papaya post-inoculadas. Carril 8: Control fitoplasma amarillamiento áster (AYIB). Carril 9: Vacío. Carril 1, 10: Marcador (1 Kb plus DNA Ladder, Invitrogen Life Technologies, EE.UU).

Figure 2. AluI (A) and MseI (B) RFLP patterns based on the BTSp 16S rDNA sequence. Lanes 2, 3: Field-collected papaya and E. papayae. Lanes 4, 5: E. papayae used in transmission trial. Lanes 6, 7: Papaya plants post-inoculated. Lane 8: Aster yellows phytoplasma (AYI-B) control. Lane 9: Empty. Lane 1, 10: Marker (1 Kb plus DNA Ladder, Invitrogen Life Technologies, USA).

Trial) and papaya plants post-inoculated (BTSpIB-Post) exhibited identical AluI and MseI RFLP patterns (Fig. 2). These were identical to those of the reference control, group Aster Yellows (AY) phytoplasma, subgroup 16SrI-B (AY-IB) and when compared to those previously reported (Lee et al. 1998). Nucleotide sequence and phylogenetic analysis

The BTS phytoplasma 16S rDNA sequence from the post-inoculated papaya seedlings (GenBank Accession No KP722522) showed a 99, 9\% identity with that of the field-collected papayas (GenBank Accession No KP722520) and E. papayae (GenBank Accession No KP722521), and including to the previously reported BTS phytoplasma (GenBank Accession No JF781308), member of the subgroup 16SrI-B.

The $s d h$ A sequence of rickettsia from the postinoculated papaya seedlings (GenBank Accession No KP722525) presented a $100 \%$ of sequence identity with those of rickettsia strains identified 


\begin{tabular}{|c|c|c|c|c|}
\hline Category & $\begin{array}{c}\mathbf{N}^{\circ} \\
\text { samples }\end{array}$ & $\begin{array}{c}\text { nPCR/RFLP } \\
\text { (phytoplasma) }\end{array}$ & $\begin{array}{c}\text { PCR } \\
\text { (rickettsia) }\end{array}$ & $\begin{array}{c}\text { Mix } \\
\text { infections }\end{array}$ \\
\hline BTS-affected papaya plants (field) & 45 & 36 & 42 & 36 \\
\hline E. papayae adults (field) & 8 & 6 & 5 & 4 \\
\hline E. papayae nymphs (field) & 15 & 9 & 12 & 8 \\
\hline E. papayae adults post- inoculated & $\overline{15}$ & 8 & 10 & 7 \\
\hline Maradol Roja post-inoculated & 15 & 12 & 9 & 8 \\
\hline Tainung-1 post-inoculated & 15 & 6 & 7 & 6 \\
\hline Scarlet Princess post-inoculated & 15 & 9 & 6 & 6 \\
\hline Total papaya plants post-inoculated & 45 & 27 & 22 & 20 \\
\hline
\end{tabular}

Tabla 1. Detección de los patógenos fitoplasma y rickettsia en los ensayos de transmisión.

Table 1. Detection of phytoplasma and rickettsia pathogens from the transmission trials.

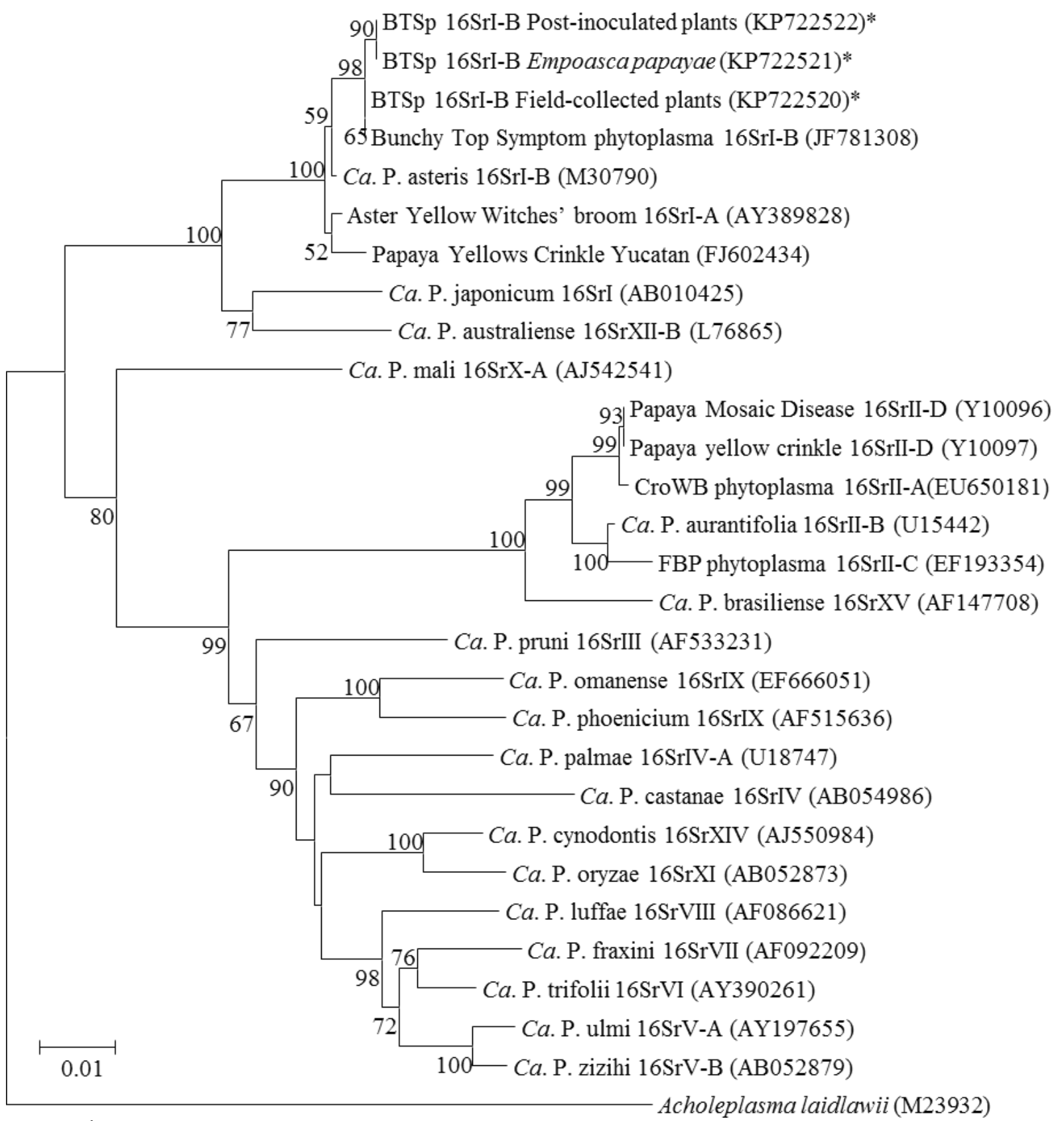

Figura 3. Árbol filogenético basado en las secuencias de ADNr $16 \mathrm{~S}$ de BTSp identificados en plantas de papaya y E. papayae empleado en los ensayos de transmisión y, otros 24 aislados de fitoplasmas. A. laidlawii se empleó como grupo externo. Aislados de este estudio se identificaron con asteriscos.

Figure 3. Phylogenetic tree based on the $16 \mathrm{~S}$ rDNA sequences of the BTSp identified in papaya plants and E. papayae used in the transmission trials and, other 24-phytoplasma strains. A. laidlawii was used as out-group. Strains of this study identified with asterisk. 


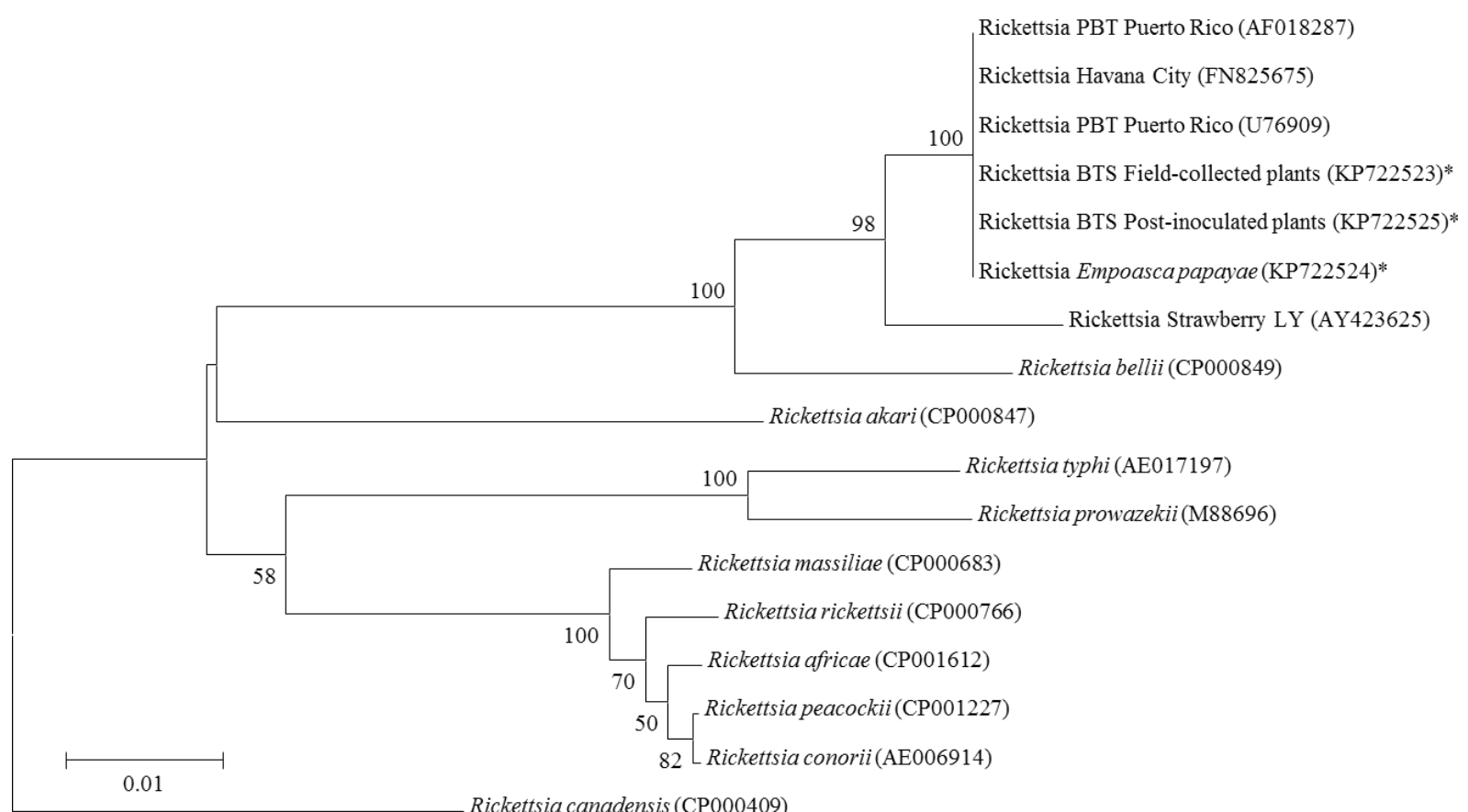

Figura 4. Árbol filogenético basado en la secuencias del gen $s d h \mathrm{~A}$ de cepas de rickettsia detectada en plantas de papaya y E. papayae. Rickettsia canadensis se empleó como grupo externo. Los valores estadísticos se muestran en los nodos. "Ca." designado para "Candidatus". Aislados de este estudio se identificaron con asteriscos.

Figure 4. Phylogenetic tree based on the sdhA gene sequence of rickettsia strains detected in papaya plants and E. papayae. Rickettsia canadensis was used as out-group. The bootstrapping values are indicated in the nodes. "Ca." stands for "Candidatus". Strains of this study identified with asterisk.

in the field-collected papaya plants (GenBank Accession No KP722523) and E. papayae (GenBank Accession No KP722524), as with the PBT rickettsia from Puerto Rico (GenBank Accession No U76909) and from Havana City (GenBank Accession No FN825675).

The phylogenetic analysis of the $16 \mathrm{~S}$ rDNAsequences (Fig. 3) showed that BTSp from the post-inoculated papayas, and field-collected papayas and E. papayae clustered in the same phylogenetic branch closely to the subgroup 16SrI-B (GenBank accession No M30790), which was confirmed by virtual RFLP analysis.

The phylogenetic tree based on the rickettsia $s d h$ A sequences (Fig. 4) confirmed that the rickettsia strains from the post-inoculated papayas, field-collected papayas and E. papayae grouped all within the same branch containing the previously reported rickettsia strains from Puerto Rico (GenBank Accession No U76909) and Havana City (GenBank Accession No FN825675).

\section{Discussion}

We confirmed the previous reported association of the group $16 \mathrm{SrI}$ phytoplasma and rickettsia with BTS in Cuba (Acosta et al. 2011, 2013). In addi- tion, our results refer to the first report of $E$. papayae as a simultaneous vector for the BTS phytoplasma and the rickettsia pathogens.

Previous reports have evidenced that high population densities of E. papayae were associated with an increasing incidence of BTS in the same papaya field (Acosta et al. 2010). The present study confirmed that actually a high incidence of E. papayae populations in the papaya fields affected by BTS, and a high number of the specimens were infected with either phytoplasma and/or rickettsia or both. The fact that 30 out of 45 post-inoculated papayas, were simultaneously infected with phytoplasma and rickettsia pathogens and showed BTS symptoms, demonstrated that $E$. papayae is a natural vector for both plant pathogens associated with BTS.

E. papayae is able to for transmit the subgroup 16SrI-B and rickettsia associated to BTS in Cuba. It is known that Dalbulus maidis (DeLong and Wolcott, 1927) is the only one vector of both "corn stunt" spiroplasma and "maize bushy stunt" phytoplasma in tropical and subtropical areas of the western hemisphere (Arocha and Jones 2010).

Empoasca species have been shown as both carriers and potential vectors of phytoplasmas associated with grapevine stolbur (Battle et al. 
2000, 2005), European stone fruit yellows (Pastore et al. 2004), alfalfa witches' broom (Khan et al. 2003), and lime decline (Khalid et al. 2009), including the 16SrII phytoplasma associated with BTS in Cuba (Acosta et al. 2010). Furthermore, Empoasca decipiens Paoli 1930 has been identified as the potential vector for the chrysanthemum yellows phytoplasma (CYP, " $\mathrm{Ca}$. Phytoplasma asteris", 16SrI-B) (Galetto et al. 2011).

Sequencing and RFLP analyses showed that BTS is caused by one phytoplasma, vectored by E. papayae. This belong to group $16 \mathrm{SrI}$, " $\mathrm{Ca}$. Phytoplasma asteris", subgroup 16SrI-B, associated with BTS in the western and eastern regions of the country, however E. papayae also transmit the group 16SrII " $\mathrm{Ca}$. Phytoplasma aurantifolia" in the eastern Cuba (Acosta et al. 2010).

Phylogenetic analyses showed that BTS is caused by a rickettsia strain of that identified from Puerto Rico for which E. papayae has been reported as its vector also in other countries of Central America (Davis et al. 1998).

The phytoplasma 16SrI-B subgroup and rickettsia were identified indistinctly in the postinoculated "Maradol Roja", Tainung-1 and Scarlet Princess cultivars (Table 1). This suggests that $E$. papayae is able to simultaneously transmit the phytoplasma 16SrI-B subgroup and the rickettsia to papaya cultivars, and that these pathogens may possess particular host-pathogen interaction genetic mechanisms and epidemiological constraints that favour their natural simultaneous occurrence within the papaya hosts.

The transmission by E. papayae of the BTSp and rickettsia pathogens from BTS-affected papaya plants to phytoplasma-free papaya plants where BTS-like symptoms were reproduced and where the same phytoplasma and rickettsia pathogens were detected, confirms that E. papayae is a natural vector of both 16 SrI-B BTSp and rickettsia pathogens. Our results set the basis for the development of effective strategies for the control of $E$. papayae populations in the papaya commercial plantations and for the management of the BTS and its two phytoplasma and rickettsia pathogens associated. Future work should focus on epidemiological studies of the E. papayae vector, including the population dynamics, transmission efficiency of both plant and pathogens, and the genetic mechanisms governing the natural simultaneous occurrence in the field.

\section{Acknowledgements}

The research was supported by the International Foundation for Science (IFS) project grant D/5355-1 from Stockholm, Sweden. Similarly, the Foreign Affair Secretariat from Mexico and CIIDIR-IPN, Sinaloa has supported this research.

\section{References}

Acosta K, Piñol B, Arocha Y, Wilson M, Boa E \& Lucas J. 2010. Transmission of the Phytoplasma Associated with Bunchy Top Symptom of Papaya by Empoasca papayae Oman. Journal of Phytopathology 158: 194-196.

Acosta K, Zamora L, Fernández A, Arocha Y, Martínez Y, Santos ME, Méndez J, Chávez A \& Leyva NE. 2011. First report of 'Candidatus Phytoplasma asteris' (group 16Srl) affecting papaya in Cuba. New Disease Reports 24: 29.

Acosta K, Zamora L, Piñol B, Fernández A, Chávez A, Flores G, Méndez J, Santos ME, Leyva NE \& Arocha Y. 2013. Identification and molecular characterization of phytoplasmas and rickettsia pathogens associated with 'Bunchy Top Symptom' (BTS) and 'Papaya Bunchy Top' (PBT) of papaya in Cuba. Crop Protection 45: 49-56.

Altschul S, Gish W, Miller W, Meyers E \& Lipman D. 1990. Basic local alignment search tool. Journal of Molecular Biology 215: 403-10.

Arocha Y \& Jones P. 2010. Phytoplasma diseases of the Gramineae. In Phytoplasmas: Genomes, Plant Hosts and Vectors (Weintraub PG \& Jones P, Eds.). United Kingdom: CAB International, pp. 170-187.

Arocha $Y$, Horta D, Peralta E \& Jones P. 2003. First report on molecular detection of phytoplasmas in papaya in Cuba. Plant Disease 87: 1148.

Arocha $\mathrm{Y}$, Piñol B, Picornell B, Almeida R \& Jones $\mathrm{P}$. 2006. First report of the 16Srll ('Candidatus Phytoplasma aurantifolia') group associated with a bunchy-top disease of papaya in Cuba. Plant Pathology 55: 821.

Arocha Y, Piñol B, López M, Miranda I, Almeida R, Wilson M \& Jones P. 2007. 'Bunchy Top Symptom' of papaya in Cuba: new insights. Bulletin of Insectology 60 (2): 393-394.

Battle A, Angeles-Martínez M \& Laviña A. 2000. Occurrence, distribution and epidemiology of grapevine yellows in Spain. European Journal Plant Pathology 106: 811-816.

Battle A, Sabaté J \& Laviña A. 2005. Epidemiology and detection of stolbur phytoplasma affecting grapevine in Spain. Phytopathology 95: S153.

Davis M, Ying Z, Brunner B, Pantoja A \& Fewerda F. 1998. Rickettsial relative associated with Papaya Bunchy Top disease. Current Microbiology 36: 8084.

Edgar RC. 2004. MUSCLE: a multiple sequence alignment method with reduced time and space complexity. BMC Bioinformatics 5: 113 
Galetto L, Marzachì C, Demichelis S \& Bosco D. 2011. Host Plant Determines the Phytoplasma Transmission Competence of Empoasca decipiens (Hemiptera: Cicadellidae) Journal of Economic Entomology 104 (2): 360-366.

Gundersen D \& Lee IM. 1996. Ultrasensitive detection of phytoplasmas by nested-PCR assay using two universal primer pairs. Phytopathologia Mediterranea 35: 144-151.

Khalid A, Arocha Y, Wilson M \& Jones P. 2009. Molecular identification, potential vectors and alternative hosts of the phytoplasma associated with a lime decline disease in Saudi Arabia. Crop Protection 28: 13-18.

Khan AJ, Botti S, Al-Subhi AM, Zaidi MA, Altosaar I, Alma A \& Bertaccini A. 2003. Molecular characterization of the 16S rRNA gene of phytoplasma detected in two leafhopper species associated with alfalfa plants infected with witches' Broom in Oman. Phytopathologia Mediterranea 42: 257-267.
Lee IM, Gundersen-Rindal DE, Davis RE \& Bartoszyk IM. 1998. Revised classification scheme of phytoplasma based on RFLP analysis of 16S rRNA and ribosomal protein gene sequences. International Journal of Systematic Bacteriology 48: 1153-1169.

Moir ML, Brennan KEC, Majer JD, Fletcher MJ \& Koch JM. 2005. Toward an optimal sampling protocol for Hemiptera on understorey plants. Journal of Insect Conservation 9: 3-20.

Pastore M, Baffone E, Santonastaso M, Priore R, Paltrinieri S, Bertaccini A \& Simeone AM. 2004. Phytoplasma detection in Empoasca decedens and Empoasca spp. and their possible role as vectors of European Stone Fruit Yellows (16SrX-B) phytoplasma. Acta Horticulturae 657: 507-511.

Tamura K, Stecher G, Peterson D, Filipski A \& Kumar S. 2013. MEGA6: Molecular Evolutionary Genetics Analysis Version 6.0. Molecular Biology Evolution 30: 2725-2729. 